\title{
Study on Marketing Behaviour of the Cashew Farmers of Tamil Nadu
}

\author{
A. Rajkala ${ }^{1^{*}}$ and R. Jansirani ${ }^{2}$ \\ ${ }^{1}$ Department of Extension Education, Tamil Nadu Agricultural University, \\ Coimbatore -641003, India \\ ${ }^{2}$ (Agrl. Extension) Department Sustainable Organic Agriculture, Tamil Nadu \\ Agricultural University, Coimbatore -641003, India \\ *Corresponding author
}

\begin{abstract}
A B S T R A C T
Marketing of cashew nut is not properly organized. The channel consists of the producer, village merchant, wholesalers or agents and exporters. Since it is an activity restricted to only three months in a year, there are no exclusive traders for raw cashew nuts. Often there are intermediaries or wholesalers between the traders and manufactures who provide the services of information and make the deal. This has resulted in middleman playing an important role in the marketing of nuts thereby reducing the margin or dividends for the cashew farmers. The present study was aimed to find the marketing behaviour of cashew farmers of Ariyalur District, Tamil Nadu. The study reflected the relationship of characteristics of the cashew farmers with their marketing behaviour. The study was conducted in three blocks of Andimadam, Sendurai and Jayankondam of Ariyalur district. Two villages from each block were selected for study purpose. The total sample size was 180 respondents comprises of 60 farmers were selected in each block. Majority of the respondents had medium level of marketing behaviour. Without value addition, the nuts were being sold as raw in after harvest in village itself to the local traders. Cashew nuts were sold by majority of the respondents whenever there was fair price for nuts based on demand of the produce in the market. Majority of the farmers were transported the cashew through tempo van and so transport cost was low. Majority for the cashew growers were discussed with neighbours, friends and relatives. The age, experience in cashew cultivation, and perceived effectiveness of training were found to have positive and significant contribution with dependent variable marketing behaviour of Cashewnut farmers at 1 per cent of probability. Educational status, family type, social participation and extension linkage were found to have positive and significant contribution with dependent variable marketing behaviour of Cashewnut farmers at 5 per cent of probability.
\end{abstract}

\section{Introduction}

Cashew/Cashewnut (Anacardium occidentale L.) is one of the important horticultural crops in India. The crop has a great commercial value and in recent years it has gained a considerable importance due to its profitable trade and export earnings. Cashew is mainly cultivated in Asia, Africa and Latin America. Country-wise analysis of area under cashewnut indicates that India has the maximum area $(21.60 \%)$ under its cultivation.

In India, this crop is widely grown in the states of Andhra Pradesh, Goa, Karnataka, 
Kerala, Maharashtra, Tamil Nadu, Orissa and West Bengal. In Tamil Nadu cashew is the one of the major plantation crop, which is being grown under 91058 ha .Cashew production is $57988 \mathrm{MT}$ and productivity is 0.64 MT per hectare. The major cashew growing districts of Tamil Nadu are Ariyalur, Cuddalore, Villupuram, Pudukottai, Sivagangai and Theni. (Source: Department of Horticulture and Plantation). Though the area under Cashewnut cultivation is high in Ariyalur District, the productivity level is up to $400 \mathrm{~kg} / \mathrm{ha}$.

Marketing of cashew nut is not properly organized. The channel consists of the producer, village merchant, wholesalers or agents and exporters. Since it is an activity restricted to only three months in a year, there are no exclusive traders for raw cashew nuts. Often there are intermediaries or wholesalers between the traders and manufactures who provide the services of information and make the deal. This has resulted in middleman playing an important role in the marketing of nuts thereby reducing the margin or dividends for the cashew farmers (Kalam, 1994). So it is indispensable to analyse the marketing behaviour of cashew farmers.

\section{Materials and Methods}

The study was focused on cashew farming in an attempt to assess the marketing behaviour by the cashew farmers. In Ariyalur district, cashew cultivation is a predominant one. Further, in the State, Ariyalur district stands first in the cashew cultivation and with the coverage of 30,343 ha. Considering the above facts, Ariyalur District was selected purposively for this study. A sample 180 samples of respondents from Andimadam, Sendurai and Jayankondam block were selected through based on Random Sampling Technique procedure was employed in selecting 60 respondents each from block.
The marketing behaviour of cashewnut farmers was studied with the identified 10 components namely time of sale, price fixing criteria, mode of sale, mode of transport, expenditure incurred on transport, place of sale, reason for selection of market, distance of the market, source of market information and collection of money. The marketing behaviour of cashew farmers were ascertained through closed type questions and interpreted by percentage analysis. The data were collected through a well-structured and pretested interview. The statistical tools of cumulative frequency, arithmetic mean, percentage analysis, correlation and multiple linear regression, were used to analyse the collected data. The findings were meaningfully interpreted and relevant conclusions were drawn.

\section{Results and Discussion}

\section{Distribution of cashewnut farmers according to their item-wise marketing behaviour}

The distribution of cashewnut farmers according to their item-wise 1 marketing behaviour of respondents explained in Table 1 .

\section{Time of sale}

With regard to time of sale, 71.67 per cent of the respondents sold the entire produce immediately after harvest whereas 28.33 per cent sold their produce when the price was attractive. Most of the respondents were marginal and small farmers and they would be normally in need of money for meeting their farm, home expenses and children education. And also no storage facilities by cashewnut farmers in the study area So they sold their produce either immediately after harvest or after initial storage. Farmers were not aware and lack of knowledge and infrastructure 
facilities about value addition. So, Most of the farmers were not concentrate value addition in cashewnut.

\section{Price fixing criteria}

Vast majority $(86.67 \%)$ of the cashewnut farmers fixed the price based on demand for the produce followed by more than ten (13.33\%) per cent of the respondents fixed the price based on cost of production. The reason was that mostly farmers would expect the more the returns. In cashewnut cultivation, cost of production was less. So, cashewnut farmers fix the price based on demand for the produce rather than based on cost of production.

\section{Mode of sale}

Three - fourth $(78.89 \%)$ of the respondents sold their produce through local merchant followed by wholesalers $(16.11 \%)$ and contractors $(5.00 \%)$. Majority of the respondents sold their produce directly to local merchants and whole sale merchants because they needed immediate payments for their produce. Further, they were easily approachable and familiar to the respondents. These local merchants/whole sale merchants were providing financial assistance when they are in need of money. The above reasons would have motivated them to sell their produce to local merchants and whole sale merchant.

\section{Mode of transport}

Majority $(81.10 \%)$ of the respondents used tempo van/tractor for transporting their produce followed by moped and bicycle of the respondents 6.67 and 6.67 percent respectively. Only meager $(5.56 \%)$ used lorry for transporting their produce. During the survey, it was observed that most of the respondents sold to local merchants and wholesalers. They were owned tractor and therefore they utilized it to transport the produce to nearby towns and outside the towns. Bicycles and moped were used for transporting the produce within the local village and nearby villages. Very meager per cent of the respondents used lorry for transporting the produce too far off places.

\section{Expenditure incurred on transport}

More than three - fourth $(82.22 \%)$ of the respondents had low level of expenditure on transport followed by medium $(12.78 \%)$ and high $(5.00 \%)$. The reason behind this was that most of the respondents sale the products in village itself. So, local merchants buy the products and take in own vehicle. So, Majority of the Cashewnut farmers incurred expenditure on transport is low.

\section{Place of sale}

Nearly half $(62.77 \%)$ of the respondents sold their produce in the village followed by 15.00 per cent of the respondents sold in their field itself, 11.67 per cent sold in the nearby town and a meager per cent $(10.56 \%)$ sold their produce to other states/ districts. Local merchants and whole salers were take products in farmer village itself. So, majority of the cashewnut farmers would have preferred the local sale in the village itself.

\section{Reason for selection of the market}

About 84.44 per cent of the respondents selected the market based on the higher place followed by nearness to the place of production (20.56\%) and meager percent $(5.00 \%)$ of cash payment . Most of the respondents were marginal and small farmers and so they do not want to spend more money on transport. Thus, they chose/select the markets based on the higher place and nearness to their place of production. 


\section{Distance of the market}

More than three -fourth (78.89\%) of the respondents marketed their produce in the markets located at the distance of up to $5 \mathrm{~km}$. Around 11.66 per cent of the respondents transported their produce within the distance of $11-15 \mathrm{~km}, 9.44$ per cent of the respondents transported their produce to the distance of 5$10 \mathrm{~km}$.

Majority of the respondents sold their products in the nearby town and village because better price and demand was more in the semi urban areas. Hence most of the respondents preferred such a semi urban / urban areas.

\section{Source of market information}

Above half $(56.11 \%)$ of the respondents came to know the price trends in the market through relatives and friends followed by retailers $(31.11 \%)$,local marketing centres $(5.00 \%)$ commission agents $(6.11 \%)$, contractors $(1.67 \%)$ and retailers $(1.11 \%)$. The reason may be that the farmers living in the villages were found to have acted as the sources of market information to a vast majority of the respondents. The respondents also received market information through relations, friends and retailers.

\section{Collection of money}

Above one third (37.22\%) of the respondents sold their produce for immediate payment of money. About 29.44 per cent of the respondents collected money within 1-2 days after sale of the produce and 13.33 per cent of the respondents collected money after a week of sale and 11.11 per cent of the respondents collected money a month after sale. Only a meager per cent $(8.89 \%)$ of the respondents collected money after 15 days after sale. Majority of the respondents sell their produce for immediate payment of money to meet their expenses of homestead activities and also to clear the debts.

\section{Distribution of cashewnut farmers according to their preference of market channel}

Marketing channels consist of channel members who perform many functions. Marketing channels particularly, indirect channels (wholesaler, retailer and agents) perform many functions to facilitate availability of products to consumers with ease. Their functions offer benefits or services to manufactures on one hand and to the consumers on the other hand. Marketing channel plays a crucial role for both producers and ultimate consumers. It is a vital link between the primary producers and the ultimate consumers. A list of four predominant marketing channels were identified and given to the cashewnut farmers for ranking according to their performance. The relevant data were obtained and the results are tabulated in Table 2.

The data in Table 2 revealed that majority (87.5 Garrett score) of the respondents preferred to market their produce through Channel 1 because this includes direct marketing from producer to consumer and does not include any middle man. This was followed by channel 2 (62.5 Garrett score) which includes producer, retailer and consumer.

Similarly, Rank III was given to the Channel 3 which included producer, wholesaler, retailer and consumer and had Garrett score of about 37.50. Rank IV was given to the Channel 4 (12.50 Garrett score) which included producer, commission agent, wholesaler, retailer and consumer. Majority of the respondents preferred to sell their produce directly from producer to the consumers for 
avoiding the middle man. The respondents also expressed that marketing the produce directly to consumers would be helpful for the farmers to obtain higher price for their cashewnut. This finding is in line with Karpagam (2019).

\section{Overall marketing behaviour of the cashewnut farmers}

The distribution of respondents according to their overall marketing behaviour is presented in Table 3.

It could be inferred from Table 3 that nearly two-fourth $(60.55 \%)$ of the respondents had medium level of marketing behaviour, whereas 23.89 per cent of respondents had low level of marketing behaviour followed by 15.55 per cent of respondents with high level of marketing behaviour respectively.

Therefore, it may be concluded that majority of the respondents $(76.10 \%)$ were found under medium to high level of marketing behaviour.

The probable reason for this result might be good knowledge about the marketing trend when price is attractive, fixed the price based on demand for the produce and preferred to market their produce direct market without middleman, so as to get good price for their produce. This finding was in conformity with the finding of Venkatesan (2000).

Correlation and Multiple regressions of profile character of cashewnut farmers with their marketing behaviour

To study the relationship between the characteristics and the marketing behaviour of the respondents, simple correlation coefficient and regression analysis were carried out. The findings were presented and discussed below Table 4.
Association of profile character of cashewnut farmers with their marketing behaviour

It could be seen from table 4 that regarding marketing behaviour of cashewnut farmers, out of seventeen independent variables, eleven variables viz., age $\left(\mathrm{X}_{1}\right)$,education status $\left(X_{2}\right)$, occupation $\left(X_{3}\right)$, family type $\left(X_{4}\right)$,farm size $\left(\mathrm{X}_{5}\right)$, experience in cashew cultivation $\left(\mathrm{X}_{6}\right)$, innovativeness $\left(\mathrm{X}_{11}\right), \quad$ perceived effectiveness of training $\left(\mathrm{X}_{13}\right)$, market potential $\left(\mathrm{X}_{15}\right)$, market channel $\left(\mathrm{X}_{16}\right)$ and storage facility $\left(X_{17}\right)$ were found to have positive and significant association with dependent variable marketing behaviour of cashewnut farmers at 1 per cent level of probability. The variables viz., extension linkage $\left(\mathrm{X}_{10}\right)$ and awareness about training centre $\left(\mathrm{X}_{12}\right)$ were found to have positive and significant association with dependent variable marketing behaviour of cashewnut farmers at 5 per cent level of probability.

Contribution of profile character of cashewnut farmers with their marketing behaviour

From the Table 4, it could be observed that the coefficient of multiple determinations ' $\mathrm{R}^{2}$, was 0.686 . The ' $F$ ' value was significant at one per cent level. The $\mathrm{R}^{2}$ value indicated that all the 17 variables taken together, accounted for 68.60 per cent of variation in the dependent variable namely marketing behaviour of cashewnut farmers.

The prediction equation was fitted in as follows.

\begin{tabular}{|c|c|c|}
\hline 00 & $k *$ & + \\
\hline $0.043\left(\mathrm{X}_{3}\right)^{\mathrm{NS}}$ & $+0.100\left(\mathrm{X}_{4}\right)^{*}$ & $-0.093\left(\mathrm{X}_{5}\right)^{\mathrm{NS}}$ \\
\hline$+0.390\left(\mathrm{X}_{6}\right)^{* *}$ & $-0.198\left(\mathrm{X}_{7}\right)^{\mathrm{NS}}$ & $+0.155\left(\mathrm{X}_{8}\right)^{*}-$ \\
\hline $0.108\left(\mathrm{X}_{9}\right)^{\mathrm{NS}}$ & $+0.220\left(\mathrm{X}_{10}\right)^{*}$ & $-0.058\left(\mathrm{X}_{11}\right)^{\mathrm{NS}}$ \\
\hline $\begin{array}{l}+0.053\left(\mathrm{X}_{12}\right)^{\mathrm{NS}} \\
0.036\left(\mathrm{X}_{15}\right)^{\mathrm{NS}}+\end{array}$ & $+0.271\left(\mathrm{X}_{13}\right)^{* *}$ & $\left.\mathrm{X}_{14}\right)^{*}$ \\
\hline
\end{tabular}


Table.1 Distribution of Cashewnut farmers according to their item-wise marketing behaviour $(\mathrm{n}=180)^{*}$

\begin{tabular}{|c|c|c|c|}
\hline S. No. & Particulars & Number & Per cent \\
\hline I & \multicolumn{3}{|l|}{ Time of sale } \\
\hline a. & As soon as harvest & 129 & 71.67 \\
\hline b. & When price is attractive & 51 & 28.33 \\
\hline c. & After value addition & 0 & 0 \\
\hline II & \multicolumn{3}{|l|}{ Price fixing criteria } \\
\hline a. & Based on cost of production & 24 & 13.33 \\
\hline b. & Based on demand for the produce & 156 & 86.67 \\
\hline III & \multicolumn{3}{|l|}{ Mode of sale } \\
\hline a. & Local Merchants & 142 & 78.89 \\
\hline b. & Contractors & 9 & 5.00 \\
\hline c. & Whole salers & 29 & 16.11 \\
\hline d. & Commission mandi & 0 & 0.00 \\
\hline IV & \multicolumn{3}{|l|}{ Mode of transport } \\
\hline a. & Bicycle & 12 & 6.67 \\
\hline b. & Tempo van/ Tractor & 146 & 81.10 \\
\hline c. & Moped & 12 & 6.67 \\
\hline d. & Lorry & 10 & 5.56 \\
\hline $\mathbf{V}$ & \multicolumn{3}{|l|}{ Expenditure incurred on transport } \\
\hline a. & High & 9 & 5.00 \\
\hline b. & Medium & 23 & 12.78 \\
\hline c. & Low & 148 & 82.22 \\
\hline VI & \multicolumn{3}{|l|}{ Place of sale } \\
\hline a. & Field itself & 27 & 15.00 \\
\hline b. & In the Village & 113 & 62.77 \\
\hline c. & Nearby town & 21 & 11.67 \\
\hline d. & Other State/ District & 19 & 10.56 \\
\hline VII & \multicolumn{3}{|l|}{ Reasons for selection of market } \\
\hline a. & Nearness to the place of production & 37 & 20.56 \\
\hline b. & Higher price & 152 & 84.44 \\
\hline c. & Cash payment & 9 & 5.00 \\
\hline VIII & \multicolumn{3}{|l|}{ Distance of the Market } \\
\hline a. & Up to $5 \mathrm{~km}$ & 142 & 78.89 \\
\hline b. & $5-10 \mathrm{~km}$ & 17 & 9.44 \\
\hline c. & $11-15 \mathrm{~km}$ & 21 & 11.66 \\
\hline IX & \multicolumn{3}{|l|}{ Source of market information } \\
\hline a. & Relation and friends & 101 & 56.11 \\
\hline b. & Local marketing centers & 9 & 5.00 \\
\hline c. & Commission agents & 11 & 6.11 \\
\hline d. & Contractors & 3 & 1.67 \\
\hline e. & Retailers & 56 & 31.11 \\
\hline $\mathbf{X}$ & \multicolumn{3}{|l|}{ Collection of money } \\
\hline a. & Immediately after sale & 67 & 37.22 \\
\hline b. & 1-2 days after sale & 53 & 29.44 \\
\hline c. & A week after sale & 24 & 13.33 \\
\hline d & 15 days after sale & 16 & 8.89 \\
\hline e & A month after sale & 20 & 11.11 \\
\hline
\end{tabular}


Table.2 Distribution of cashewnut farmers according to their preference of marketing channel $(n=180)$

\begin{tabular}{|c|c|c|c|c|}
\hline S. No. & Channel No. & Description & Garrett Score & Rank \\
\hline 1. & Channel 1 & Producer - Consumer & 87.5 & Rank I \\
\hline 2. & Channel 2 & Producer - Retailer - Consumer & 62.5 & Rank II \\
\hline 3. & Channel 3 & $\begin{array}{l}\text { Producer - Wholesaler - Retailer - } \\
\text { Consumer }\end{array}$ & 37.5 & Rank III \\
\hline 4. & Channel 4 & $\begin{array}{l}\text { Producer - Commission agent - } \\
\text { wholesaler - Retailer - Consumer }\end{array}$ & 12.5 & Rank IV \\
\hline
\end{tabular}

Table.3 Distribution of respondents according to their overall marketing behavior $(\mathrm{n}=180)$

\begin{tabular}{|c|lr|c|c|}
\hline S. No. & \multicolumn{2}{|c|}{ Category } & Number & Per cent \\
\hline $\mathbf{1 .}$ & Low $(<21)$ & 43 & 23.89 \\
\hline $\mathbf{2 .}$ & Medium $(21$ to 40$)$ & & 109 & 60.55 \\
\hline 3. & High $(>40)$ & Total & $\mathbf{1 8 0}$ & $\mathbf{1 0 0 . 0 0}$ \\
\hline & & ren \\
\hline
\end{tabular}

Table.4 Correlation and multiple regression analysis between the profile characteristics and marketing behaviour of organic farmers

\begin{tabular}{|c|c|c|c|c|c|}
\hline V. No. & Variables & $\begin{array}{c}\text { Pearson } \\
\text { Correlation }\end{array}$ & $\begin{array}{c}\text { Partial } \\
\text { Regression } \\
\text { Coefficient }\end{array}$ & SE & 't' value \\
\hline X1 & Age & $0.291^{* *}$ & 0.166 & 0.075 & $2.132 * *$ \\
\hline $\mathbf{X} 2$ & Educational Status & $0.284^{* *}$ & 0.122 & 0.048 & $1.565^{*}$ \\
\hline $\mathbf{X 3}$ & Occupation & $0.306^{* *}$ & 0.043 & 0.237 & $0.545^{\mathrm{NS}}$ \\
\hline X4 & Family type & $0.247^{* *}$ & 0.100 & 0.361 & $1.275^{*}$ \\
\hline X5 & Farm size & $0.389^{* *}$ & -0.093 & 0.090 & $-1.183^{\mathrm{NS}}$ \\
\hline X6 & Experience in cashew cultivation & $0.483^{* *}$ & 0.390 & 0.083 & $5.376^{* *}$ \\
\hline $\mathbf{X} 7$ & Annual income & $-0.047^{\mathrm{NS}}$ & -0.198 & 0.078 & $-2.567^{\mathrm{NS}}$ \\
\hline $\mathbf{X 8}$ & Social Participation & $-0.032^{\mathrm{NS}}$ & 0.155 & 0.103 & $1.987^{*}$ \\
\hline X9 & Information source exposure & $-.0 .155^{*}$ & -0.108 & 0.044 & $-1.373^{\mathrm{NS}}$ \\
\hline $\mathbf{X 1 0}$ & Extension linkage & $0.154^{*}$ & 0.220 & 0.084 & $2.855^{*}$ \\
\hline X11 & Innovativeness & $0.205^{* *}$ & -0.058 & 0.167 & $-0.733^{\mathrm{NS}}$ \\
\hline $\mathbf{X 1 2}$ & Awareness about training centre & $0.156^{*}$ & 0.053 & 0.457 & $0.672^{\mathrm{NS}}$ \\
\hline $\mathbf{X 1 3}$ & Perceived effectiveness of training & $0.282^{* *}$ & 0.271 & 0.041 & $3.566 * *$ \\
\hline X14 & $\begin{array}{l}\text { Perceived effectiveness of cashew } \\
\text { cultivation }\end{array}$ & $-0.086^{\mathrm{NS}}$ & -0.255 & 0.095 & $-3.344 *$ \\
\hline X15 & Market potential & $0.259^{* *}$ & -0.036 & 0.506 & $-0.458^{\mathrm{NS}}$ \\
\hline X16 & Market channel & $0.261^{* *}$ & 0.013 & 0.447 & $0.163^{\mathrm{NS}}$ \\
\hline $\mathbf{X 1 7}$ & Storage facility & $0.275^{* *}$ & -0.096 & 0.069 & $-1.230^{\mathrm{NS}}$ \\
\hline \multicolumn{6}{|c|}{$\begin{array}{ll}\text { Constant }=0.899 & \text { NS }- \text { Non-significant } \\
\mathrm{R} 2=0.686 & *-\text { Significant at } 5 \% \text { level } \\
\mathrm{F}=8.432 * & * * \text { - Significant at } 1 \% \text { level }\end{array}$} \\
\hline
\end{tabular}


As evident from results that the values of regression co-efficient of the variables, age $\left(\mathrm{X}_{1}\right)$,experience in cashew cultivation $\left(\mathrm{X}_{6}\right)$ and perceived effectiveness of training $\left(X_{13}\right)$ were found to have positive and significant contribution with dependent variable marketing behaviour of cashewnut farmers at 1 per cent of probability. Educational status $\left(\mathrm{X}_{2}\right)$, family type $\left(\mathrm{X}_{4}\right)$, social participation $\left(\mathrm{X}_{8}\right)$ and extension linkage $\left(\mathrm{X}_{10}\right)$ were found to have positive and significant contribution with dependent variable marketing behaviour of cashewnut farmers at 5 per cent of probability. Perceived effectiveness of cashew cultivation(X14) was found to have negative and significant contribution with dependent variable marketing behaviour of cashewnut farmers at 5 per cent level of probability.

Occupation $\left(\mathrm{X}_{3}\right), \quad$ farm $\operatorname{size}\left(\mathrm{X}_{5}\right)$, annual income $\left(X_{7}\right)$, information source exposure $\left(X_{9}\right)$, innovativeness $\left(\mathrm{X}_{11}\right)$, awareness about training center $\left(\mathrm{X}_{12}\right)$, market potential $\left(\mathrm{X}_{15}\right)$, market channel $\left(\mathrm{X}_{16}\right)$ and storage facility $\left(\mathrm{X}_{17}\right)$ were not significant contribution with dependent variable marketing behaviour of cashewnut farmers.

The strength of these significant variables can be explained as ceteris paribus. The results inferred that an unit increase in age $\left(X_{1}\right)$, experience in cashew cultivation $\left(\mathrm{X}_{6}\right)$ and perceived effectiveness of training $\left(\mathrm{X}_{13}\right)$ increases the marketing behaviour of cashewnut farmers by $0.166,0.390$ and 0.271 respectively. The results, thus proved that age, experience in cashewnut cultivation and perceived effectiveness of training positively contributed to the marketing behaviour of cashewnut farmers. It might be due the fact that, in the study area majority of the cashewnut farmers had middle age and high experience in cashewnut cultivation for increasing marking behaviour of cashewnut farmers. And also majority of the cashewnut farmers had capable to more capable of perceived effectiveness of training. This finding is in line with Arularasi (2009).

\section{References}

Arularasi, R. (2009). Comparative Study on Yield, Quality, Marketing and Price aspects of Banana grown under Organic and Inorganic Farming Conditions. (Unpub.

M.Sc. (Ag.) Thesis), TNAU, Coimbatore.

Kalam, Abdul, M. (1994). Problems and prospects of cashew cultivation in Kerala. Proceedings of National Seminar on Development of Cashew Industry. Directorate of Cashewnut Development, Cochin. PP. 78.

Karpagam,D.2019."An Analytical Study on Technology Utilization and Marketing behaviour of Organic paddy farmers in cauvery delta zone of TamilNadu." Unpub. Ph.D. Thesis, TNAU, Coimbatore.

Venkatesan, S. (2000). Awareness, knowledge and adoption level of recommended tomato cultivation practices in Tamil Nadu. Unpub. M.sc.(Ag.) Thesis, Department of Agricultural Extension and Rural Sociology, TNAU, Coimbatore.

\section{How to cite this article:}

Rajkala, A. and Jansirani, R. 2020. Study on Marketing Behaviour of the Cashew Farmers of Tamil Nadu. Int.J.Curr.Microbiol.App.Sci. 9(05): 2514-2521. doi: https://doi.org/10.20546/ijcmas.2020.905.288 